\title{
Towards a Pro-Silience Framework: A Literature Review on Quantitative Modelling of Resilient 3PL Supply Chain Network Designs
}

\author{
Evangelos Gkanatsas ${ }^{1}$ and Harold Krikke ${ }^{2, *(1)}$ \\ 1 Kuehne + Nagel Management AG, 8834 Schindellegi, Switzerland; evangelos.gkanatsas@ou.nl \\ 2 Faculty of Management, Science and Technology, Open University of the Netherlands, Valkenburgerweg 177, \\ 6419 AT Heerlen, The Netherlands \\ * Correspondence: Harold.Krikke@ou.nl
}

Received: 28 April 2020; Accepted: 19 May 2020; Published: 25 May 2020

check for updates

\begin{abstract}
The increasingly dynamic and volatile market environment has elevated the importance of handling operational risks in supply chain networks. Also, black swan risks are constantly evolving and can strike from almost anywhere, including natural disaster, cyber risk, or viruses. As more companies are outsourcing their logistics to third-party logistics (3PL), at the same time, supply chain risks and uncertainties are also shifted to 3PLs. A 3PL's supply chain network capability to assure continuity can be expressed in terms of resilience, i.e., the ability of sensing and responding to disturbances or threats. Operations research/management science (OR/MS) methods have been widely applied in supply chain management. The objective of this paper is to look into research regarding the development of resilient 3PL supply chain network designs through the utilization of OR/MS methods. After extensive literature review, a so called pro-silience framework is developed aiming at improving resilience from a 3PL perspective maintaining or increasing its competitive advantage during and after major disruptions, yet also maintain competitiveness under normal operating conditions. Additionally, the framework offers insights into topics for future research.
\end{abstract}

Keywords: literature review; 3PL; resilience; quantitative models; OR/MS; black swan disruptions; competitive advantage; pro-silience; supply chain network design

\section{Introduction}

Supply chain networks (SCN) are dynamic, complex systems calibrating the interplay of interdependent components. Due to their interconnectedness, problems that used to remain isolated now can escalate rapidly and cause significant disruptions [1]. Inspired from the study of resilience in the field of biology [2], a supply chain follows the property of resilience when designed with the ability to foresee disruptions and effectively respond to these in order to restore its original state or transcend to a better one [3-5].

The formation of the new, global economic landscape has driven companies to outsource their logistics activities to third-party logistics (3PL) providers for the sake of competitiveness [6-8]. Based on the 2019 third-party logistics study [9], 53\% of shippers' transportation and 34\% of their warehouse operations expenditure are related to outsourcing. Accordingly, opportunities arise to improve customer services, eliminate assets, be more agile, and focus on core business. However, supply chain risks and uncertainties are also shifted to 3PLs. Incontrovertibly, 3PL's operational performance cannot always be guaranteed under deviating conditions [10,11]. 3PL's inability to deliver during disruptions may result in extinction and exit from the market [12,13]. For example, the impact of the Corona virus outbreak in February 2020 was estimated 6m Twenty-foot Equivalent Units (TEU) volume reduction 
globally for the first quarter of 2020 [14]. With almost 1000 USD per TEU [15], a USD 6 billion loss of revenue raises concern for the survival of shipping lines with less financial stability. Similarly, the ripple effect of such a disruption influence 3PLs as, for example, staff are not available to execute shipments. From a legal perspective, one is not able to fulfil contracts and special arrangements may result in more expensive ways to transport goods.

When high-impact, low-frequency 'black swan' events take place, many supply chain networks (SCNs) do not have the capacity to maintain satisfactory operational status and can only slowly recover. Nonetheless, some excelling SCNs carry out their functions readily during and after a major disruption [16]. In short, during disruptive incidents opportunities for a 3PL to retain and increase market share by outperforming its competitors exist. We postulate that the ability to adapt quickly under difficult circumstances will enhance the competitive advantage for a 3PL. It is our aim to identify and quantify these benefits through an extensive review of the literature in the field.

Literature on SC disruptions and resilience has been (and is still) growing quickly over the past few years [17]. Yet, studies conducted in the field have little reference on building resilience in 3PL SCNs. Further, although operations research (OR)/management science (MS) methods have been widely applied to supply chain management at large [18], such methods within the context of resilient 3PL SCNs have not drawn analogous emphasis. More notably, the concept of resilience as a driver not only to restore but also to revamp a 3PL SCN for obtaining a competitive advantage has received little or no attention.

This paper contributes by presenting a critical and structured review of publications from 2008 to 2019 on quantitative modelling (OR/MS) of 3PL SCNs' resilience. Based on that, we propose a OR/MS-based pro-silience framework as a starting point for future research founded onthe gaps identified. In the next section, we will define the field more precisely and position our paper relative to previous, systematic or not, literature reviews.

\section{Defining the Field and Positioning the Paper}

A major stream of publications has tried to define supply chain resilience (SCR). Rise et al. [19] defines SCR "as the ability to react to unexpected disruptions and restore to normal supply chain network operations" while Christopher and Peck [20], as "the ability of the system to return to its original state or to move to a new one more desirable after being disturbed". Ponomarov and Holcomb [21] considered important elements such as adaptive capability, unexpected events, response and recovery ability, and control over the structure. Ponis and Koronis [22] highlighted "the ability of a supply chain network to anticipate unexpected events so that can respond and transcend to a robust state of operations in the aftermath of disruptions". Also, if possible, to move to a more favorable one than that prior to the disruptive event, thus gaining a competitive advantage. Similarly, Kim et al. [23] considered SCN resilience as "a network-level attribute to withstand disruptions that may be triggered at the node (location) or arc (connection) level".

As the research in the field of SCR gains maturity [17], definitions of resilience are also evolving in an attempt to encompass the different elements of supply chains. In such complex networks, all the disturbance parameters are variable. Thus, it is difficult to adjudicate a versatile definition covering all aspects of resilience. Table 1 summarizes the various definitions. 
Table 1. Supply chain resilience definitions [17].

\begin{tabular}{|c|c|}
\hline Author & Supply Chain Resilience Definition \\
\hline Rise et al. [19] & $\begin{array}{l}\text { The ability to react to unexpected disruptions and restore normal supply } \\
\text { network operations }\end{array}$ \\
\hline Christopher and Peck [20] & $\begin{array}{l}\text { The ability of a system to return to its original state or move to a new, } \\
\text { more desirable state after being disturbed }\end{array}$ \\
\hline Ponomarov and Holcomb [21] & $\begin{array}{l}\text { The adaptive capability of the supply chain to prepare for unexpected } \\
\text { events, respond to disruptions, and recover from them by maintaining } \\
\text { continuity of operations at the desired }\end{array}$ \\
\hline Ponis and Koronis [22] & $\begin{array}{l}\text { The ability to proactively plan and design a Supply Chain network for } \\
\text { anticipating unexpected disruptive (negative) events, respond } \\
\text { adaptively to disruptions while maintaining control over structure and } \\
\text { function and transcending to a post event robust state of operations, if } \\
\text { possible, more favorable than the one prior to the event, thus gaining } \\
\text { competitive advantage }\end{array}$ \\
\hline Kim et al. [23] & $\begin{array}{l}\text { We define supply network resilience as a network-level attribute to } \\
\text { withstand disruptions that may be triggered at the node or arc level }\end{array}$ \\
\hline
\end{tabular}

For the purpose of our study with a focus on 3PL SCNs, we define resilience as the "capability of a 3PL SCN in the event of unexpected shocks of high-impact, low-probability of occurrence, to concurrently return to its original or improved situation and thrive amid disturbances without lowering its competitive advantage under normal operating conditions". To emphasize the need for purposefulness to resilience, i.e., create opportunities to attain a better position in the market in the aftermath of disruptions, we introduce the principle of pro-silience, borrowed from psychology as "the ability of a person to be intentionally prepared to face disruptions" [24].

Ponis and Koronis [22] highlighted that the developmental nature of resilience, as conceptualized in the field of psychology i.e., the ability of an entity to overcome stressing situations employing available internal and external resources, is usually neglected in the organizational resilience. To amplify the concept, we postulate that an organization should copy the pro-silience behavior of a person that is able to learn to overcome adversity by understanding the elements of resilience and deliberately practicing them [24]. Ivanov et al. [25] introduced the term "Viability" as the ability of the system to survive under a changing environment, as an essential component of resilience to ensure continuity for an intertwined SCN that interconnects different supply chains, especially when unprecedented events such as COVID-19 occur. Viable 3PL SCNs act as a focal point to coordinate and execute in parallel different SCs. A 3PL can not only survive, but also grow by creating competitive advantage. For example, Kuehne + Nagel's air logistics division managed to achieve gross profit $83 \mathrm{CHF} / 100 \mathrm{~kg}$ $(\mathrm{Q} 1,2020)$ compared to $80 \mathrm{CHF} / 100 \mathrm{~kg}(\mathrm{Q} 1,2019)$, offsetting the impact for COVID-19 due to optimal mix of cargo [26].

Thereby, within the context of 3PL SCN, we define pro-silience as a "principle whereas a 3PL SCN is intentionally designed and prepared to anticipate, survive and thrive during disruptions without compromising daily performance under normal operating conditions". In other words, to build a system that can benefit from shocks and thrive and grow under uncertainty and volatility [27]. At the same time, building resilience should not lead to higher costs, being the case when the redundancy approach is adapted [28] denoting a non-competitive 3PL SCN under normal operations. In Section 7, we will elaborate on that concept and present a conceptual framework.

To finalize this section, we define a 3PL supply chain network. A 3PL SCN comprises suppliers, manufacturing centers, warehouses, distribution centers, and retail outlets as well as channels for the flow of raw materials, work-in-process inventory, and finished products between the facilities [29]. Note that some of these activities and facilities are owned by the 3PL, but also others are part of the SCN. Typical network configuration decisions involve determining the optimal number of locations and size of warehouses in conjunction with the best distributions centers with the objective to minimize 
inventory, facility, and transportations costs. This strategic choice has a strong impact on performance and resilience and vice versa, as such optimal SCNs do not necessarily perform when exposed to disruptions.

Black swan disruptions, either caused by natural disruptions (hurricane, volcanoes, etc.) or human activities (e.g., terrorist attacks), and SCR approaches have drawn the attention of researchers $[17,30]$. Previous (systematic) literature reviews have investigated SCM and resilience combining different dimensions of the topic as well research methodology and time span. Table 2 summarizes this.

Snyder et al. [30] conducted a literature review to discuss the OR/MS methods deployed to model supply chain disruptions. One hundred and eighty scholarly works up to 2014 were reviewed, placing supply chain disruptions into six categories: (a) Strategic decisions; (b) evaluating supply disruptions; (c) sourcing decisions; (d) contracts and incentives; (e) inventory; and (f) facility location. Wang et al. [28] analyzed 43 articles and addressed the issue of viewing SCN from a holistic point of view, a set of supply chains that are interdependent. Ribeiro and Povoa [31] performed a content analysis of 39 papers in order to outline the different definitions of SCR discussed by researchers as well as the quantitative models developed to support SCR decisions. They concluded that there is no consensus on SCR definitions in the literature and that the use of quantitative models, and although their contribution to study SCR is undisputed, only a limited number of studies were conducted. Ivanov et al. [32] reviewed the quantitative methods applied considering both disruptions and recovery on proactive supply chain design and planning. They observed that the majority of quantitative research deal with demand volatility and lead-time variability in terms of operational uncertainty. They also suggested that new key performance indicators subject to uncertainty and disruptions, such a resilience and robustness, must be introduced considering both the static and dynamic properties of supply chain systems. It is also worthwhile to mention the literature review conducted by Eskandarpour et al. [33] who address the mathematical models related to SCN design. Eighty-seven papers spanning 1990-2014 were reviewed where at least two of the three aspects of sustainability i.e., "economic aspects, environmental and social responsibility" should be incorporated in the models. Their analysis showed that deterministic mixed integer linear programming models were mainly adopted, and stochastic solutions to model the uncertainty of the SCN design are needed. Additionally, although the majority of the models included two dimensions in their objective function, future research is suggested for multi-objective models utilizing goal programming and advanced heuristics solutions to tackle large scale problems.

Table 2. List of literature reviews on the topic of supply chain resilience.

\begin{tabular}{cccc}
\hline Author(s) & Title & Year & Journal Name \\
\hline Longo and Oren [34] & $\begin{array}{c}\text { Supply Chain Vulnerability and } \\
\text { Resilience. A State of the Art } \\
\text { Overview. }\end{array}$ & 2008 & $\begin{array}{c}\text { European Modelling and } \\
\text { Simulation Symposium }\end{array}$ \\
\hline Snyder et al. [30] & $\begin{array}{c}\text { OR/MS Models for Supply Chain } \\
\text { Disruptions: A Review }\end{array}$ & 2016 & IIE Transactions \\
\hline Ponis and Koronis [22] & $\begin{array}{c}\text { Supply Chain Resilience: Definition } \\
\text { of Concept and Its Formative } \\
\text { Elements }\end{array}$ & 2012 & $\begin{array}{c}\text { The Journal of Applied } \\
\text { Business Research }\end{array}$ \\
\hline Braziotis et al. [35] & $\begin{array}{c}\text { Supply Chains and Supply } \\
\text { Networks: Distinctions and } \\
\text { Overlaps }\end{array}$ & 2013 & $\begin{array}{c}\text { Supply Chain } \\
\text { International Journal }\end{array}$ \\
\hline Farahani et al. [36] & $\begin{array}{c}\text { Competitive Supply Chain Network } \\
\text { Design: An Overview of } \\
\text { Classifications, Models, Solution } \\
\text { Techniques and Applications }\end{array}$ & 2014 & Omega \\
\hline
\end{tabular}


Table 2. Cont.

\begin{tabular}{|c|c|c|c|}
\hline Author(s) & Title & Year & Journal Name \\
\hline Gorman et al. [37] & $\begin{array}{c}\text { State of the Practice: A Review of } \\
\text { the Application of OR/MS in Freight } \\
\text { Transportation }\end{array}$ & 2014 & Interfaces \\
\hline Saenz et al. [38] & $\begin{array}{l}\text { Research on the Phenomenon of } \\
\text { Supply Chain Resilience a } \\
\text { Systematic Review and Paths for } \\
\text { Further Investigation }\end{array}$ & 2014 & $\begin{array}{l}\text { International Journal of } \\
\text { Physical Distribution \& } \\
\text { Logistics Management }\end{array}$ \\
\hline Wang et al. [28] & $\begin{array}{l}\text { Toward a Resilient Holistic Supply } \\
\text { Chain Network System: Concept, } \\
\text { Review and Future Direction }\end{array}$ & 2014 & $\begin{array}{l}\text { IEEE SYSTEMS } \\
\text { JOURNAL }\end{array}$ \\
\hline Fahimnia et al. [39] & $\begin{array}{l}\text { Quantitative Models for Managing } \\
\text { Supply Chain Risks: A Review }\end{array}$ & 2015 & $\begin{array}{l}\text { European Journal of } \\
\text { Operational Research }\end{array}$ \\
\hline Gunasekaran et al. [40] & $\begin{array}{l}\text { Performance Measures and Metrics } \\
\text { in Outsourcing Decisions: A Review } \\
\text { for Research and Applications }\end{array}$ & 2015 & $\begin{array}{l}\text { International Journal of } \\
\text { Production Economics }\end{array}$ \\
\hline Ivanov et al. [32] & $\begin{array}{l}\text { Literature Review on Disruption } \\
\text { Recovery in the Supply Chain }\end{array}$ & 2015 & $\begin{array}{l}\text { International Journal of } \\
\text { Production Research }\end{array}$ \\
\hline Khan and Estay [41] & $\begin{array}{c}\text { Supply Chain Cyber-Resilience: } \\
\text { Creating an Agenda for Future } \\
\text { Research }\end{array}$ & 2015 & $\begin{array}{l}\text { Technology Innovation } \\
\text { Management Review }\end{array}$ \\
\hline $\begin{array}{l}\text { Tukamuhabwa et al. } \\
\text { [42] }\end{array}$ & $\begin{array}{c}\text { Supply Chain Resilience: Definition, } \\
\text { Review and Theoretical } \\
\text { Foundations for Further Study }\end{array}$ & 2015 & $\begin{array}{l}\text { International Journal of } \\
\text { Production Research J }\end{array}$ \\
\hline $\begin{array}{l}\text { Wankmülle and } \\
\text { Seebacher [43] }\end{array}$ & $\begin{array}{l}\text { A Citation Analysis of the Research } \\
\text { on Supply Chain Resilience }\end{array}$ & 2015 & Conference Paper \\
\hline $\begin{array}{l}\text { Kamalahmadi and } \\
\text { Parast [17] }\end{array}$ & $\begin{array}{l}\text { A Review of the Literature on the } \\
\text { Principles of Enterprise and Supply } \\
\text { Chain Resilience: Major Findings } \\
\text { and Directions for Future Research }\end{array}$ & 2016 & $\begin{array}{l}\text { International Journal of } \\
\text { Production Research }\end{array}$ \\
\hline Elleuch et al. [44] & $\begin{array}{l}\text { Resilience and Vulnerability in } \\
\text { Supply Chain: Literature review }\end{array}$ & 2016 & Conference Paper \\
\hline Ivanov et al. [45] & $\begin{array}{c}\text { Disruptions in Supply Chains and } \\
\text { Recovery Policies: State-Of-The Art } \\
\text { Review }\end{array}$ & 2016 & IFAC-PapersOnLine \\
\hline Oliveira et al. [46] & $\begin{array}{l}\text { Perspectives and Relationships in } \\
\text { Supply Chain Simulation: } \\
\text { A Systematic Literature Review }\end{array}$ & 2016 & $\begin{array}{l}\text { Simulation Modelling } \\
\text { Practice and Theory }\end{array}$ \\
\hline Govindan et al. [47] & $\begin{array}{l}\text { Supply Chain Network Design } \\
\text { Under Uncertainty: } \\
\text { A Comprehensive Review and } \\
\text { Future Research Directions }\end{array}$ & 2017 & $\begin{array}{l}\text { European Journal of } \\
\text { Operational Research }\end{array}$ \\
\hline Bak [48] & $\begin{array}{c}\text { Supply Chain Risk Management } \\
\text { Research Agenda: From a Literature } \\
\text { Review to a Call for Future Research } \\
\text { Directions }\end{array}$ & 2018 & $\begin{array}{c}\text { Business Process } \\
\text { Management Journal }\end{array}$ \\
\hline $\begin{array}{c}\text { Kochan and Nowicki } \\
{[49]}\end{array}$ & $\begin{array}{c}\text { Supply Chain Resilience: } \\
\text { A Systematic Literature Review and } \\
\text { Typological Framework }\end{array}$ & 2018 & $\begin{array}{l}\text { International Journal of } \\
\text { Physical Distribution \& } \\
\text { Logistics Management }\end{array}$ \\
\hline
\end{tabular}


Table 2. Cont.

\begin{tabular}{cccc}
\hline Author(s) & Title & Year & Journal Name \\
\hline Macdonald et al. [50] & $\begin{array}{c}\text { Supply Chain Risk and Resilience: } \\
\text { Theory Building Through } \\
\text { Structured Experiments and } \\
\text { Simulation }\end{array}$ & 2018 & $\begin{array}{c}\text { International Journal of } \\
\text { Production Research }\end{array}$ \\
\hline $\begin{array}{c}\text { Supply Chain Resilience: } \\
\text { Barbosa-Povoa [31]. }\end{array}$ & $\begin{array}{c}\text { Definitions and Quantitative } \\
\text { Modelling Approaches-A } \\
\text { Literature Review }\end{array}$ & 2018 & $\begin{array}{c}\text { Computers \& Industrial } \\
\text { Engineering }\end{array}$ \\
\hline Roy and Sengupta [51] & $\begin{array}{c}\text { Quintessence of Third Party (3PL) } \\
\text { Logistics }\end{array}$ & 2018 & $\begin{array}{c}\text { Journal of Global } \\
\text { Operations and Strategic } \\
\text { Sourcing }\end{array}$ \\
\hline Wan et al. [52] & $\begin{array}{c}\text { Resilience in Transportation } \\
\text { Systems: A Systematic Review and } \\
\text { Future Directions }\end{array}$ & 2018 & Transport reviews \\
\hline Eskandarpour et al. [33] & $\begin{array}{c}\text { Sustainable Supply Chain Network } \\
\text { Design: An Optimization-Oriented } \\
\text { Review }\end{array}$ & 2015 & Omega \\
\hline
\end{tabular}

Although attention is paid to quantitative models in SCR, combining the topic with outsourcing logistics activities to third parties and the transfer of incorporated risk such a decision entails has drawn less (if none) attention in the systematic literature reviews conducted to date. On that ground, our approach differs from previous work in two ways: First, understanding resilience from a 3PL point of view. The ability of a 3PL as main actor that connects the different nodes within a supply chain, to adapt, recover, and respond during unexpected event. Second, to investigate resilience as a property for a 3PL to survive, and more importantly, thrive amid disruption ahead of the competition a.k.a. pro-silient.

\section{Research Questions}

In line with the motivation of the paper previously outlined, the research questions below have been defined to determine the overall direction of the research. Thereafter, a conceptual pro-silience framework through the identification of research gaps on resilience and propose OR/MS methods that can furnish a competitive advantage for a 3PL both under normal operations and during disruptions.

\subsection{How Has Resilience Been Addressed in 3PL Supply Chain Networks Design?}

The key taking here is that through outsourcing, shippers transfer responsibilities and tasks but also all uncertainties and risks. Hence, 3PL SCNs must be designed to foresee, absorb, and overcome disruptions [53]. Currently, supply chains are built to deal with minor disruptions, but the event of low-frequency, high-impact disruptions may result in negative performance and losses [54]. Many companies prove unprepared. On June 2017, the NotPetya ransomware hit Maersk Line, APM Terminals, and TNT affecting the container supply chain. The disruptions resulting from the cyberattack propagated to four different locations with an estimated cost of 200m USD [55]. On 31 January 2020, Toll Group, which is part of Japan Post, was attacked by a ransomware attack and as a result had to disable some of its systems leading to delays, untraceable packages, and missed deliveries impacting their customers supply chains. These issues could be solved by ad hoc measures only. For example, due to the coronavirus outbreak in China, markets needed to redirect perishables products from Latin America or drive prices down domestically [56]. At the same time, due to sailing cancelation by the shipping lines that resulted in capacity shortages, products were left rotting in the ports creating challenges for both producers and 3PLs responsible for coordinating the supply chains. Such disruptive conditions put stress on terminal loading/unloading operations and shipping schedules considering 
limited resources in terms of equipment, buffer times, and capacities. However, the literature has addressed similar problems, and through the utilization of mathematical modelling, efficient solutions were provided to solve the flexible ship loading problem [57]. Comparatively, solutions can also be adopted for the design of 3PL SCNs supporting optimal decisions in terms of shipping schedules, modes of transport, and storage during disruptions.

\subsection{What Are the Typical Risks/Disruptions That 3PLs Are Exposed to and Can They Turn Risk into a (Business) Opportunity?}

Evolution of SC risks is inevitably both unanticipated and uncertain in nature due to lack of previous experience in terms of their impact and ability to deal with them [58] and can be generated either from the supply or demand side or external/environmental risks [59]. High-profile black swan events such as Thailand floods, hurricane Katrina, pandemics, and the global financial crisis caused tremendous disruptions in global supply chains testing their level of resilience [54]. At the same time, the digital transformation of the SC industry to meet the customer requirements requires cybercrime and security to be considered when designing a SCN.

Recently, the Coronavirus outbreak created major disruptions infecting all players of global supply chains. It was estimated that Apple may have to delay the launch of its next iPhone, planned for March 2020, by several weeks [60]. Meanwhile, 3PLs warn for capacity shortages and prices spikes when the factories will be reopened due to volume surges [61]. 3PLs with the aptitude to provide solution alternatives to their customers will avoid capacity constraints and high rates. For example, a 3PL offering an sea-air solution, moving the goods via sea to transhipment hubs and then flying to the final destination, can help customers to avoid airfreight price surges or space shortages for semi urgent shipments that cannot be shipped by sea modality only [62]. This is an example of a 3PL SCN intentionally designed to face disruptions and challenges can maintain and strengthen its competitive advantage.

\subsection{What Type of OR/MS Methods Have Been Deployed to Model 3PL Supply Chain Networks under Disruptions to Optimize the Pro-Silience Strategies?}

Logistics is one of the dynamic activities that enable the connection between production and consumption [63]. Considering the business environment in which 3PL SCN are designed to function, metrics such as frequency, punctuality, geographical coverage, costs, and transit times are dominant. Exploiting optimization and stochastic modelling is useful when capturing the dynamic nature and the associated risks as part of or disturbing these metrics [17]. By utilizing OR/MS methods to tackle and quantify the complexity of the real world, good solutions can be obtained to design 3PL resilient SCN. Yet, supply chain risks have not been adequately quantified so that appropriate strategies are available to either avoid them or at least minimize their effect [64]. Our objective is to identify those risks and trigger further research on the field so that effective and efficient quantitative OR/MS methodologies can be developed within the 3PL domain.

On a second note, when disruptions occur, their impact cascade throughout the arcs and node of a 3PL SCN. In other words, and as defined by Scheibe and Blackhurst [65], 3PL SCNs are exposed to the propagation of disruptions, which is the spread of a disruption further to its origin location. Depending on the structure of the SCN as well as the frequency of disruptions, propagation can either result in the bullwhip (high frequency/low impact) or ripple effect (low frequency/high impact) [66]. To mitigate the rippling of disruptions in the network, we need to understand how disruptions can affect the SCN performance in relation to the duration of disruptions and recovery policies [67]. OR/MS methods can offer rigorous experimentations and evaluation of all possible scenarios. A 3PL SCN designed to anticipate disruptions when these occur can transit to a pro-silient state. By this we mean a state that SCN can function well during-and better after-disruptions without reducing the 3PL performance in normal state of business activities. 


\section{Methodology}

The aim of a literature review is to provide collective insights through theoretical synthesis into fields and sub-fields. In order to limit bias in the collection of the relevant academic work and ensure that conclusions are based on reliable findings, explicit methods were used [68,69]. Articles were collected, selected, and reviewed following the methodology employed by Fahimnia [39], Kamalahmadi and Parast [17], and Barbosa-Povoa [70] to answer the research questions [71].

In preparing the sample for this study, we considered the publications in peer reviewed, English-written journals, from 2008 to 2019. We used 2008 as a starting point because it is the beginning of the financial crisis. As a result of the credit crunch, an overemphasis on cost reduction has increased the vulnerability of today's global supply chains [72]. The focus was on quantitative OR/MS studies, qualitative studies were excluded, hybrids were not. Inclusion/exclusion criteria were applied to obtain a list of eligible articles relevant to the purpose of the study.

We used Web of Science (WS) and Science Direct (SD) as search databases and selected a first batch of papers using search keywords based on the terminologies used in supply chain risk management including previous literature reviews on the field of SCR [17,31]. Keywords were combined in Boolean logic to formulate the strings used to search the database whereas in each string, the term 3PL was included. Consecutively, we reiterated the search using the same string but replaced the term 3PL to "Third Party Logistics".

A content analysis was conducted on the abstracts and title of the articles resulting from the search. Those relevant with the defined keywords were retained. More specifically, we extracted and documented information through first the scanning of abstracts, conclusions, and subsequently-if feasible- the body of the article to select those papers that satisfy the concept of supply chain resilience from a 3PL network design perspective and that apply quantitative or hybrid (combination of qualitative/quantitative) methods.

Figure 1 portrays the major steps taken in this methodology. The search in both databases WS and SD resulted in a total number of articles 7524, however upon removing duplicates and articles not related to supply chain management and resilience, a sample of 1680 was collected. By applying the inclusion/exclusion criteria defined, 328 articles were reviewed based on the title and abstract that resulted in 110 articles. Performing a full screening, 28 articles were eventually chosen to be included in the analysis based on the relevance to the area of focus of this study.

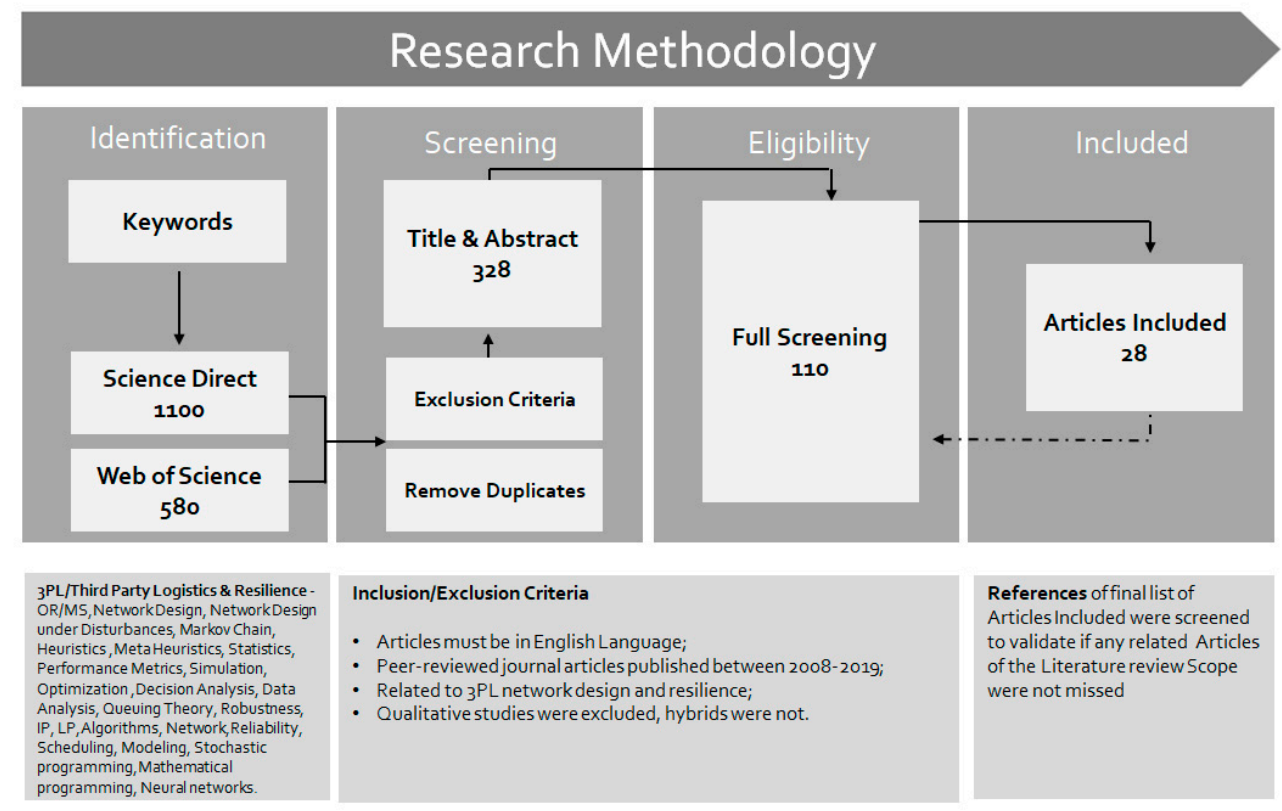

Figure 1. Prisma flow diagram for literature review [73]. 


\section{Results/Findings}

In the section below, we classify the articles collected through the methodology applied to answer the research questions.

\subsection{Research Question (1)}

First, we try to identify how academics have perceived 3PL SCNs resilience as an integral part of supply chain management. When sub-functions of the SCN are outsourced to a 3PL, the degree to which a company can strategically collaborate with its supply partners" $[12,74,75]$ will determine the supply chain integration (SCI). This is an important element for a company to maximize value to the final customer. Given that a positive relation exists between SCI and SCR [20,76], Liu and Lee [77] tested a number of hypotheses to investigate this relation from an outsourcing perspective. They hypothesized that positive relations exist between 3PL service performance and SCR. A greater level of resilience will lead 3PL to better foresee potential disruption and proactively resolve them. Data were collected through questionnaires and by deploying partial least squares structural equation modeling (PLS-SEM/PLS), the research hypotheses were tested. The results of this study revealed that SCR and performance are directly linked. Higher internal integration as well as (external) customer integration can both improve SCR and thus performance. In contrast, collaborative logistics through sharing information, equipment, and risk between different customers only indirectly enhances SCR of the logistics integrator and its service performance via customer integration.

Giri and Sarker [78] have considered a supply chain consisting of three participants: A monopolistic manufacturer, a 3PL, and multiple independent retailers in dispersed geographical locations. With the objective to improve the coordination among them, a Stackelberg model was developed. Considering that 3PLs play a vital role to ensure a smooth flow of materials directly affecting its customers and their profits, they studied how production disruption at the source (manufacturer) may affect supply chain decisions. Further, they examined how resilience can be improved under different types of contract between the 3PL and retailers (buyback and revenue sharing contracts). Assuming that market demand is stochastic in nature and influenced by the retail price, two scenarios were evaluated. (1) The 3PL has enough capacity to satisfy the demand of retailers in a centralized supply chain. Under this setup, the three participants reach an agreement that part of the per-unit logistic service charge will be borne by the manufacturer and the remaining part will be borne by the retailer. (2) A decentralized SCN where each party maximizes its profit and it is assumed that the manufacturer is responsible to manage the activities of the three parties to ensure that the overall performance of the SC is improved. The setup does not involve any contractual agreement among the parties. Based on their analysis, in the centralized system, the profit of the supply chain depends largely on the logistics costs for delivering the products from manufacturer to retailers. As a consequence, a lack of ability of the 3PL to mitigate disruptions will increase cost of logistics services inflating the retail price of the products. In the decentralized system, the manufacturer may gain from disruptions by setting higher wholesale prices to retailers. This is due to the monopolistic behavior of the manufacturer. That will result in lower profits of the whole supply chain. The quality of the service provided by the 3PL will determine the level (of reduction) of the SC profits. Hence, it is critical to select a 3PL that can work cost effectively and reliable within a SCN.

Noroozi et al. [79] developed two mixed-integer linear programming models for integrated production-distribution scheduling. The objective of the models is to maximize the total revenue of accepted orders subject to the cost delivery that is outsourced to a 3PL. The manufacturer receives a pool of orders from its customer whilst the 3PL is responsible for allocating these to its fleet of vehicles. The decision of how many orders can be accepted or rejected is subject to the objective of maximizing the total net profit (TNP). One of the main findings was that by contracting a 3PL (with delivery dates promised) the total SCN cost can be reduced iincreasingthe TNP. The 3PL can deploy a larger number of vehicles to serve multiple customers simultaneously. Thus, the cost of delays and deliveries can be minimized, positively affecting the TNP. 
Ma et al. [80] studied the coordination of a three-echelon SCN. The network was formed based on one supplier, a 3PL, and a retailer of fresh agricultural products. Dynamic game models for both the decentralized and the centralized decision modes were constructed to assess the coordination among the three actors of the SCN. Further, for the decentralized setup, uncertainty was considered as a representation of asymmetric demand information. Among their findings, they discovered that the profits of the 3PL are expected to decrease when efforts to keep the products fresh are higher. However, incentive mechanisms to facilitate information sharing and sharing of the associated risks among the parties involved can improve the effort of keeping the perishables products fresh. Thus, events that will prolong the SC from production to consumption events can be avoided e.g., such as the decision of farmers temporarily storing the products in the 3PL facilities in order to achieve a higher price when there is shortage of production. Similarly, Cai et al. [81] examined the optimal decisions for a perishables SCN with three participants; a producer, a 3PL, and a retailer. Three scenarios were studied: A centralized (all three working together), a decentralized (each party works autonomous), and partially centralized (two parties join their efforts) system. The optimal levels of the price for transportation provided by the 3PL the price and products quantity offered by the producer, as well as products ordered and price sold by the retailer, were determined. It was found that outsourcing the transportation to a 3PL will positively affect the performance of the SCN. Chan et al. [82] examined the oligopolistic competition among companies as a result of the integration of SCNs. They constructed a dynamic equilibrium model to identify the level of production and flow of products that will lead to profit maximization of the companies in a closed loop supply chain (CLSC). Within this setup, activities related to delivery/distribution as well as returns and storage were incorporated. The associated costs of these activities were considered time dependent due to seasonality fluctuation of the demand and returns. Based on their results, the seasonality of (actual) demand will impact the optimal decisions the companies of the CLSC will pursue. Thus, planning ahead could also support the different companies to maximize their interests. Tsang et al. [83] dealt with a cold chain network in order to minimize the food spoilage rate during transportation executed by logistics service providers. The model aims to improve customer's satisfaction by improving operational efficiency. To maximize the life cycle of the products, Taguchi method, usually adopted to test the quality of different product designs, was utilized to identify the optimal packaging. Further, with the use of genetic algorithms (GA) and internet of things (IoT-based delivery routing that can minimize the spoilage rate of the products was determined. The model application was tested for a 3PL in Hong Kong and showed that the initial capital invested by the 3PL for infrastructure would have been recovered within 8.2 months.

\subsection{Research Question (2)}

Second, in order to assess the resilience of a SCN, a 3PL must not only evaluate exposure to risks that can affect its own operations but also those initiated by its SC partners [84]. Successful 3PLs are those that can appropriately select partners or sub-contractors to ensure inter firm flow of goods is reliably executed $[85,86]$. Based on our review, the risks a 3PL faces can be categorized in five broad categories: Internal, external, financial, customer related, and collaborative risks [87]. Internal risks include risks include IT breakdown, low quality of services performed by subcontractors, unqualified staff, and shortage of equipment to carry out transport activities. External risk, which can affect all the players in the supply chain, include employee strikes, terrorist attacks, natural disaster, and staff shortage [88]. Financial risks include exchange rates, taxes, fuel prices, and lack of access to capitals [87]. Risk originated from the customer side include planning and forecasting, trust, information sharing, opportunism, and dependency risks as well as payment related risk. Other examples are inadequate level integration among the SC partners (i.e., suppliers, retails, customers, 3PLs) triggered by asymmetric knowledge of the services provided, distorted or poor level of information. Collaborative risks due to lack of cooperation between the different parties may affect the performance of a 3PL considering that they must interact with the different participants and design services that meet their needs [89]. 
We can also classify their effect as time-based, finance-based and quality-based. Vilko and Hallikas [84] attempt to quantify the impact of these different kinds of risk by simulation with built-in time delay to determine the probability of occurrence and their impact in SCNs. Similarly, Nel et al. [90], by using a classification of disruptions as intra-extra organizational, prove that failure of 3PLs systems and processes as well as labor strikes (including labor errors) and organizational change (including employee turnover) represent the most critical array of disruptions faced by 3PLs. Extra-organizational disruptions include those beyond the control of the 3PL, such as natural disaster-adverse weather, earthquakes/tsunami, political instability, and frequent changes in regulations by authorities as well as poor infrastructure. Further, terrorism together with cross-border transportation are an important source of disruptions for South Africa (geographical location of their study). Although the research community extensively describes the risks 3PLs SCN are exposed to, their impact, as well as the cause effect between groups and categories of risks, the ability of a 3PL to handle such risk in order to generate a business opportunity has not been explicitly addressed. Unforeseen disruptions can create shortages similar to the demand spikes caused by supply/demand imbalances; and resilient systems can thus react to changing markets ahead of their competitors [91]. For example, in 2000, Royal Philips Electronics B.V. plant in Albuquerque, New Mexico was struck by a lightning damaging millions of microships. Nokia Corp. and Telefon AB L.M. Ericsson were customers of the same plant. Nokia reacted right away and new suppliers were used to cover the shortage of microchip supply. Instead, Ericsson did not turn to a multi sourcing supply policy. When the plant was shut down, Ericsson faced major disruptions in its production that lasted for month [92]. Thereby, Nokia managed to strengthen its position as the European market leader. In 2011, the tsunami in Japan stopped the production of Xirallic pigments due to closure of the factory operated by Merck Chemicals for three months. Manufacturers that depended on a single sourcing policy lost the opportunity to increase their market share and their inability to respond to the disruptive event led to production stoppage [93]. Opposite, Caterpillar made it possible to modify production schedules so that the factory continued to operate. By the same token that applies to brand owners, 3PLs SCNs may be able to react to disturbances by deploying either proactive or reactive strategies and outperform competitors. MacKenzie et al. [94] developed a multiregional input-output (I-O) model to analyze how closure of production plants can be compensated through inventory mitigation strategies and changes in consumer behavior that may lead to substitution of products and services under scarcity from other geographical locations. The study was based on data collected during the Japanese earthquake. Although production stoppage in Japan for 17 industries (including both direct-indirect impact) led to USD 78.1 billion losses, consumer sales data showed production loss of only USD 3.7 billion. The difference was covered by imports, thus other countries and their industries benefited. Likewise, such major disruptions could be beneficial for 3PL able to accommodate similar trade shifts between national economies. For example, during the Coronavirus outbreak in China, with an effect of 5000 tons less capacity per day, DSV offered a unique solution by operating the Panalpina's 747-8F aircraft three times a week-both east and westbound-between Huntsville and Shanghai [95]. The Huntsville hub and spoke model (with express connection to Canada and Latin America) would connect all continents whilst DSV having full control of the charter capacity and ensuring ground handling of the cargo to uncongested airports [96]. DSV managed to benefit out of the disruption and position itself in the market ahead of competition creating a competitive advantage amid a major shock. The academic community has addressed similar scheduling problems for air and sea transportation. Considering disruptions such as congestion in ports [97] as well as terminal operational disruption [98], mathematical models were developed to enhance the ability of planners to examine a vast array of all possible interventions so that optimal recovery can be achieved.

Lam and Bai [99] defined the top three resilience measure that includes contingency planning (for risks such as natural disaster, piracy/terrorism, port state control), monitoring and maintenance (effective for IT risks, operational risks), and supply chain relationship management (useful for promoting collaboration, visibility, and transparency among the supply chain players). Finally, advanced IT systems, strategic alliances (effective for technical downtime), and forecast accuracy 
(effective for congestion in port and natural disasters). Zhang et al. [89] suggests that firms investing in digital technologies can provide a platform for better integration of the SCN participants and thus higher resilience. Such developments can offer enhanced information sharing to respond quickly to changing environments, allowing logistics flexibility in the system. Govindan and Chaudhuri [87] provided key recommendations that include more customer-orientated services, improvement of flexibility of their operations, as well as expansion of the geographical coverage of their services. For companies that outsource their logistics activities to 3PLs, they also recommended to consider them as strategic partners, build trust, and achieve a higher degree of information sharing. This could be seen as a first attempt towards pro-silience. The challenge is to build in these measures in 3PL SCN design.

\subsection{Research Question (3)}

Third, given the complexity and the dynamic environment in which 3PLs are operating, supply chain decision making can be improved through the deployment of computation modelling [100]. Supply chain resilience and OR/MS modelling approaches combined are fairly new for the research communities [31] and the importance for future research has been highlighted in the literature $[17,64,101]$. Methodologies applied for the identification of risks usually involves data collection through questionnaires and validation of the different categories from industry experts as well literature review analysis $[84,87,89,90]$. Pfohl et al. [88] applied interpretive structural modelling in order to examine the interrelated nature of SC risks across its the different levels (e.g., 3PL, first-tier supplier, focal company, etc.) so that it is possible to map how these risks are interconnected. Within the domain of 3PL SCN design and resilience, the methodologies applied include analytical models, simulation, graphical, and hybrid models.

Analytical models addressing the resilience of 3PL include linear programming, mixed-integer programming, goal programming, and stochastic programming. Wu [102] formulated a two-stage stochastic mixed 0-1 programming model to satisfy customer demand while minimizing the total logistics costs for a 3PL involved in cross-border transportation of goods by road including storage in both countries. Ko and Evans [103] developed a genetic algorithm-based heuristic in order to optimize the forward and return SCN simultaneously. Due to the dynamic market environment, the requirements for warehousing and transportation operations change over time. A mixed-integer nonlinear programming model that is a multi-period, two-echelon, multi-commodity, capacitated network design problem was adopted. To deal with the complexity of such NP hard models, a genetic-based heuristic algorithm was developed to obtain an improved solution. Kayvanfar et al. [104] proposed a multi-objective multi echelon mathematical supply-distribution model. The problem was solved using goal programming to minimize the costs for warehousing and logistics services offered by 3PL, to maximize demand satisfaction rate, and the quality of delivery i.e., higher service levels and more frequent deliveries. Hu et al. [105] introduced an optimization model with a three-index math-heuristic algorithm to jointly optimize the design of hub location, hub capacity, and fleet size for a 3PL. To incorporate uncertainty in the model congestion on routes was considered by formulating travel time as an increasing function of state (the number of trucks on the route). Janic [106] proposed a model for optimizing the resilience of an airline cargo transport network when affected by large-scale adverse weather conditions. The methodology applied was based on the analytical generic model of resilience of the network developed by Janic [107] for estimating the resilience, the friability defined as the diminishing rate of air transport network resilience after removing particular components such airports/air routes, and the costs of an air transport network. Ishfaq [108] addressed the issue of transportation disruptions. Two models were developed based on a minimum-cost network flow approach. The objective of the models was to enhance the resilience of the logistics operations through flexibility of multiple origin-destination pairs, transfer of costs, as well flexibility in transit times and service levels. Hendriks et al. [109] considered the uncertainty a 3PL faces in terms of the control on supply and demand of the products distributed to the different consumers. A predictive control model 
with a rolling horizon was used as decision support on an operational level. A network heuristic approach was proposed to determine the tactical decision of the network topology and operational level shipments routing and scheduling. A bi-objective mixed-integer linear programming model was developed by Rahbari et al. [110] for the vehicle routing and scheduling problem of perishable products. Given that products are stored at a cross dock before 3PLs using trucks (either refrigerated or non) to deliver to the final customers, the deterioration of these products is a direct problem for the 3PL. The vehicle routing with cross-dock mathematical problem under uncertainty was then reformulated in two robust models. For the first model, the travel time of vehicles was considered uncertain and for the second, the level of freshness of the perishables products.

Simulation models include Monte Carlo Simulation, discrete event simulation, and aged based modelling-multi agent system. Leung et al. [111] dealt with the problem of shipment planning for an air freight forwarder under uncertainty whereas the 3PL, through consolidation, can achieve on-time delivery at low cost. They have formulated the problem based on an optimization-simulation-revision framework making use of actual airline data and routings. Cheong et al. [112], considered the 3PL network design problem by evaluating the appropriate number and location of consolidation hubs. The proposed 3PL consolidated network was designed to serve multiple clients while total logistics costs were minimized. A number of different hub designs was simulated to obtain the optimal solution and observed that the Lagrangian relaxation method always finds a tighter bound solution than the LP relaxation. Coliccgia et al. [113] focused on a global SCN setup where manufacturers, suppliers, and consumers are operating in geographically dispersed locations. Uncertainty in the form of longer variable lead time was considered. Four contingency plans were simulated and further developed based on feedback from business matter experts. The contingency plans were classified on two dimensions: Increasing cost and decreasing lead time for inbound supply. The simulation model was tested in a case study involving a home appliance retailer, based in Northern Italy with suppliers located in the Beijing area (China).

Graphical models include Markov networks. Yang et al. [114] investigated the resilience of a physical internet (PI) freight transportation system that faces random disruptions. Inspired by Digital internet, the PI aimed to integrate a heterogeneous logistics network into an open, interconnected, global logistic system through standardized containers and logistics protocols. The objective was to identify if PI will enhance the resilience of a SCN given that its nodes (warehouses and distribution centers) are interconnected and the transportations means can be organized dynamically based on the changing economic environment. Considering that disruptions may occur at any time and for any length of time, at hubs of the network, they formulated a two-state Markov process, with a probability of breakdown and a probability of repair. It was assumed that logistics operations will shut down in the event of disruptions and with no possibility to resume until the end of the disruptive event. A multi-agent simulation was used to test the protocol's performance (total logistics cost, emissions, average lead time) under disruptions (due to equipment failures or labor strikes) without destroying in-site stocks. Accordingly, they proposed two resilient transportation planning strategies: A risk avoidance one and a risk-taking one. Risk avoidance strategies would be more efficient in terms of costs and emissions for shorter lead time service requirements. Under disruptions with higher probability of occurrence, such as machine breakdowns, the transportation protocols with risk-taking strategy will be more advantageous.

We have also identified hybrid models in the literature, using both qualitative and quantitative approaches. SCN under uncertainty and the opportunities adopting transport flexibility was studied by Naim et al. [115]. Action-research-based approach was applied in a steel SCN involving a 3PL, a consigner, and a consignee. The model evaluated 3PL's capacity to perform its activities providing different types and levels of flexibility that can offer opportunities to accommodate uncertainty. Huo et al. [116] investigated the 3PLs opportunistic behavior often damaging collaboration with their customers. A number of hypotheses were tested including the element of demand uncertainty. Survey data were collected from 247 manufacturing and service companies in China. They revealed that 
trust can curb opportunism benefiting all parties involved. Although detailed contracts can enhance trust, if such contracts are exploited to exercise more tight control and strict requirements, then the opportunistic behavior will increase. The less-advantaged party will seek opportunities to benefit, otherwise harming the trust and collaboration of the two parties. Finally, a decision-making trial and evaluation laboratory (DEMATEL), usually adopted to analyze interrelationship and interdependencies, was deployed by Govindan and Chaudhuri [87] to provide insights of how risks from one category and (sub-)category influence risks of other category/(sub-)category. Analytic hierarchy process (AHP) and Dematel were deployed by Fartaj et al. [117] to classify the interrelationships of disruptions in transportation identified for an automotive SCN that could be extended to 3PLs. The best-worst method (BWM) to determine the weights of decision makers and the rough strength relation (RSR) to rank the disruption factors were applied in order to represent how disruptions are linked together.

Finally, uncertainty as a parameter to indicate the level of previous knowledge of disruptive events and their impact [106] have been classified by Govinda et al. [47] in three main groups: (1) Uncertainty as a stochastic parameter following either a known continuous or discrete probability; (2) uncertainty as random parameter (discrete or continuous) with no previous information in relation to the probability of occurrence. In this group, robust optimization is utilized when uncertainty is discrete whilst if continuous some intervals are predefined (interval-uncertainty modelling). Lastly, (3) uncertainty as fuzzy parameter in situations of poor information.

In our review, the majority of the papers fall within the first classification considering uncertainty in demand-supply with known probabilities. Under group two, Rhabari et al. [110] considered the uncertainty of vehicle travel times as well as the uncertainty level of the freshness of perishable products as random and thus robust optimization was applied. Further, Kristianto [118] applied fuzzy logic, which tackles the complexity of inventory allocation and transportation routing, while Kayvanfar [104] adopted the "triangular fuzzy parameter" in order to overcome the lack of complete information related to demand, level of productions, and purchasing quantities. Low-frequency, high-impact events can be classified in group 2, yet our review has identified no papers related to 3PL SCNs regarding black swans, with the exception of Janic [106]. They assumed that heavy storms during Easter time follow a Poisson process with certain density.

\section{Literature Review Analysis and Discussion}

The field of SCR gained momentum for academics and practitioners due to recent high-profile disruptions [30]-yet the resilience of SCNs with 3PL as a main actor within a supply chain has not been explored. Along with our research questions, we discuss a number of dimensions that need further investigation.

\subsection{Resilience and 3PL Supply Chain Networks}

The outsourcing decision is almost exclusively examined within a second-party logistics provider (2PL) setup where logistics providers act as distributors $[77,118]$ or just offer warehousing services. As mentioned, today's complex and interconnected supply chains require logistics services on behalf of a manufacturer or distributor of products with global coverage. At the same time, new supply chain concepts, such as just-in-time to reduce inventory, shorter product replacement cycles, and reducing costs have stimulated a wider array services more vulnerable to risks [119]. Existing studies fail to represent how, with the formation of such complex systems, uncertainty can be managed when part or all SC activities are outsourced to 3PLs [46].

SCN design decisions can be broken down into strategic, tactical, and operational level [109]. Most of the models developed refer to the tactical planning in order to optimize the number, locations of warehouse, number of hubs, fleet size, and capacities [103,105,108,109,112,114]. Similarly, models referring to the operational level in terms of routing and scheduling $[102,111,115]$ have been also developed whilst in some models, the interplay between tactical and operational level was considered $[106,109]$. The centralization-decentralization decision was often brought forward, 
highlighting that better integration among the SC actors will mitigate the impact of disruptions. It also appears that building in resilience goes beyond the physical layer of the SCN, as IT and collaborations are essential aspects of SCI. With regards to the strategic decisions that determine the planning and design of a SCN, Iris et al. [120] explored the application of genetic algorithms (GA). GA is a technique to deal with large complex SCN problems more effectively compared to conventional optimization models. Related studies were also categorized and gaps in the literature identified. More specifically, a need for multi objective GA exists, as most of the models deal with cost of minimization of a single objective. Real-world applications to test the effectiveness of such models is also required together with expanding into more complex systems that consider, for example, multiple modes of transportation as well as decision variables that follow a probability law. Combining simulation with GA may offer an approach to deal with such challenges. Further, they suggested that current GA should be enhanced to incorporate essential supply chain activities such as inventory-and fleet planning, vehicle routing, and scheduling.

Synchronization of all the parties involved within a supply chain is crucial as the insufficient performance of one link of the chain directly affects all the others. Therefore, information sharing, collaboration, flexibility, agility, and redundancy are major principles of supply chain resilience. However, these principles were reviewed from a holistic point of view where a focal organization has the responsibility to design and control the SCN and apply mitigation strategies. Under this setup, the literature currently assumes that logistics activities are outsourced to 3PLs as they can optimize SCNs best. In the occurrence of unexpected events, 3PLs have built resilience into their SCN to respond, since 3PLs supply chain networks are more complex systems consisting of various functional entities and multi-scale interactions among them [77].

\subsection{Supply Chain Risk and Disruptions as a Source of Competitive Advantage}

A number of studies have identified extra-organizational supply chain risks that can affect 3PLs, originating either from the suppliers or customers' side. For the time span time of our review, we have identified one quantitative paper by Janic [106] referring to a large-scale disruptive event, i.e., a snowstorm resulting in airport closures. Quantitative papers related to black swan events, ergo low-probability, high-impact similar to Thailand's floods, Japan's earthquake, or the recent Corona pandemic, affecting 3PL SCNs have not been identified. There are also operational risks, which are primarily internal.

Three types of strategies were mentioned: Contingency planning, monitoring and maintenance, and relationship management, feasible for different kinds of risk. These strategies were subcategorized as reactive and proactive. Proactive strategies are applicable before the occurrence of disruptive events whilst reactive strategies are applicable during the impact of disruptive events [106]. The majority of the models have adopted a proactive approach whereas the SCN has been optimally designed taking into consideration a number of disruptions [103-105,109,111]. Reactive strategies have drawn less attention $[108,113,115]$. From our review, we conclude that a strategy dominant for all the different scenarios does not exist, which is in line with Janic [106] who underlined that proactive or reactive strategies can be combined to increase the resilience of a network depending on the nature of disruptions, SC objectives, and frequency of disruptions [114]. From a freight forwarder point of view, Janic [106] stressed that 3PLs who have the ability to temporarily change the transport mode under given conditions can deliver shipments to the final consignee overcoming disruptions. In parallel, an assessment of the strategies for building resilience for a 3PL in terms of competitiveness already under normal operations (proactive) and exploring business opportunities during/after disruptions (reactive) has not been researched yet.

Literature suggests that the feasibility of strategies depends on the nature and objectives of the SC. Yet, comparison of the existing SC strategies to identify the best fit has not be studied [17]. In the context of 3PL, having as an objective to manage different customers, different supply chains with different requirements at the same time, resilience principles must be flexible enough to adapt to meet 
this variety. Also, we have included models related to the multi-modality of transportation. Such models can offer insights into how disruptions will impact operations and applicable strategies that can help 3PLs to react and recover. 3PL SCN design should be flexible enough to re-establish the planned operational status or switch to an alternative design than initially planned and anticipating disruptions must be researched [67].

The literature appreciates that a tradeoff exists between resilience and cost effectiveness of a supply chain [20]. As soon, most of the models have been constructed on a cost minimization basis, resilience strategies and their associated costs will increase the overall costs of the supply chain execution. That being said and considering that 3PL profit margins for logistics providers got thinner due to lower load factors, resulting from shorter lead-times, narrower time windows, and smaller quantities demanded by shippers [121], 3PLs resources to build resilience are limited if not none. Therefore, resilient logistics services can only be offered as a premium option at higher cost. Only then the concept of pro-silience built in the design of 3PL SCN may prove a business opportunity for 3PLs.

\subsection{Quantitative Models to Address, Measure, and Improve 3PL SN Resilience}

We have presented analytical, simulation, and graphical methods to optimize a 3PL SCN design with built-in resilience holistically. Still, quantification of risks from a 3PL point of view has not been discussed in the literature. In fact, the occurrences of risks 3PLs are exposed to have been qualitatively measured with the tendency to either overestimate or underestimate their impact [85].

The digital transformation initiated by many 3PLs over the past years has led to the introductions of new cybersecurity risks affecting cyber-resilience of the supply chain [122]. 3PLs act as alignment among the different participants of a supply chain. New IT cloud-based systems, digital platforms, and mobility solutions have definitely elevated the role of information technology in SCs [20,122]. However, the digital surface exposed to cyberattacks has also been increased. In the event of such attacks, interrupting the information flow digitally transmitted, critical data especially on time-sensitive supply chains will not be available any longer, leading to serious damages.

Limited studies have dealt with the design of 3PL supply chain networks under disruptions and the application of OR/MS methods with main modelling approaches simulation and optimization. In the literature, models are considered to be static and deterministic, which often do not fully represent dynamics of reality [31]. Thus, their applicability under real-time situation needs to be validated. Due to a lack of historical data, it is difficult to estimate the parameters of disruptions. For the models developed, it is not very clear whether robustness or resilience is the main objective [29]. Terms are used interchangeably, but in most cases, models are built to cope with a specific range of disruptions and maintain functionality in the event of unexpected shocks. Further failure in one link of the 3PL SCN could lead to a total failure of the network [19].

Ivanov et al. [123] developed a simulation model to test the performance of a SCN during an epidemic outbreak motivated by COVID-19. Based on different scenarios, their study offers insights regarding the SC's ability to react and cope with the propagation of disruptions in terms of duration, location, as well as all demand-supply disruptions together at once. Among their findings, disruption propagation plays a vital role in the performance of a SC.

\subsection{Future Research}

From a 3PL point of view, and under an outsourcing setup of logistics activities, once we are able to move resilience toward pro-silience, 3PLs can generate a competitive advantage through offering alternative solutions to the market. Applying OR/MS methods in a coherent way is indispensable in this. This merits better understanding and further research of the 3PL SCN design and execution. An array of areas to steer efforts for additional research to incorporate the pro-silience concept could potentially include:

- SC resilience principles: A 3PL SCN can be considered a nested system, that is a separate network with nodes that are not connected with the nodes of their customers. Therefore, further research on 
how the SCR principles can be accommodated in the design phase of 3PL SCN must be conducted. Moreover, it is important to understand within a 3PL context and to quantify how these principles can be an improvement. Towards this direction, the trade-off of building a resilient 3PL and the required investments can be explored. This may also mean that formation of new network structures must be investigated. During the COVID-19 outbreak, it was observed that the SC of flowers from Kenya to Holland that acts as a main hub of the global flower trade [124], faced major disruptions due to deploying the air capacity to higher in demand, high-margins products such as pharmaceuticals. With no demand in place, producers in Kenya may be forced to switch their productions to other agricultural products in order to survive. This development would signal the shift of production from Africa to Latin America, placing Colombia as the new global hub of flowers trade. 3PLs must be in a position to offer solutions to their customers that can accommodate such alterations in their SCN design. Furthermore, during the pandemic crisis, customers asked their 3PLs to delay their shipments by moving them through transhipments hubs and speed up when the demand revamped.

- 3PL mitigation strategies achieving pro-silience: This calls for further investigation to identify the risks based on their point of origin [125], i.e., outside and within the 3PL SCN, to determine the likelihood of the sequence of events and how these will affect the different parts of the SCN [86] including estimation of probabilities of occurrence to be assigned to the different disruptive events [126]. This will allow framing strategies and solutions alternative in particular with regards to black swan events that will not only help a 3PL to survive, but also to grow. For example, switching transportation modes, in the case of flowers from Kenya to Holland via sea transport, could be a possibility to keep the flow running. Moreover, due to the recent pandemic in China, road transporters needed to find new supply routes due to congestion and travel restrictions [127] including a multimodal strategy in order to reach the final destinations. Firms like Instafreight, an online freight booking platform, offered a new road route to connect China and Europe whereas truckers could bid for a cargo assignment [127]. Under this notion, an avenue for possible research is the emphasis of competitive advantage opportunities under disruptions without compromising performance in normal situations.

- Propagation of uncertainty: In the event case of low-probability, high-impact events, the vulnerability of the network shows $[67,128]$. The concept of propagation of disruptions in these situations must be researched within a 3PL SCN equally to the ripple effect, in order to develop and test interventions. Such scenario evaluation can provide useful insights to estimate how disruptions can propagate and identify mitigation strategies to isolate their impact. Deng et al. [129] described the risk propagation chain for a perishables SCN whereas risks can form a network as an integral part of the SC. Based on this approach, risk can not only be transmitted or isolated, but can also mutate. Note that mutation can be negative, neutral, or positive. Exploring the positive impact of risk mutation within a 3PL SCN would offer opportunities to create a competitive advantage. For example, when a link of the network fails in the 3PL SCN, cargo could be redirected to other active links while exploring opportunities for optimal cargo and route mix.

- Deployment of OR/MS methods: It is evident from the literature there is a lack of OR/MS methodologies, including application of these in real-time problems in relation to 3PLs and resilience. Therefore, models to enhance 3PLs ability to operate effectively and efficiently especially in the event "black swan" disruptions, such as natural disasters, extreme weather conditions, earthquakes, pandemics, as well as cyberattacks [41] is crucial. Methods must be applied in a coherent way, which expresses the need for a conceptual OR/MS-based framework. We therefore introduce our conceptual framework in the next section.

\section{Conceptual OR/MS Based Framework of Pro-Silience}

A pro-silient 3PL SCN can deliver under smooth circumstances, but at the same time is deliberately designed to thrive as a result of unexpected shocks and volatility. To this end, hybrid application of the 
principles of SCR—-derived from mitigation strategies described in the literature-must be adopted. Figure 2 presents a conceptual framework illustrating the relationships between the different elements of the design of a 3PL SCN using OR/MS methods. They comprise the different steps from the design of the network, assessing the impact of any potential disturbances and the evaluating recovery actions to be taken, thereby creating new business opportunities.

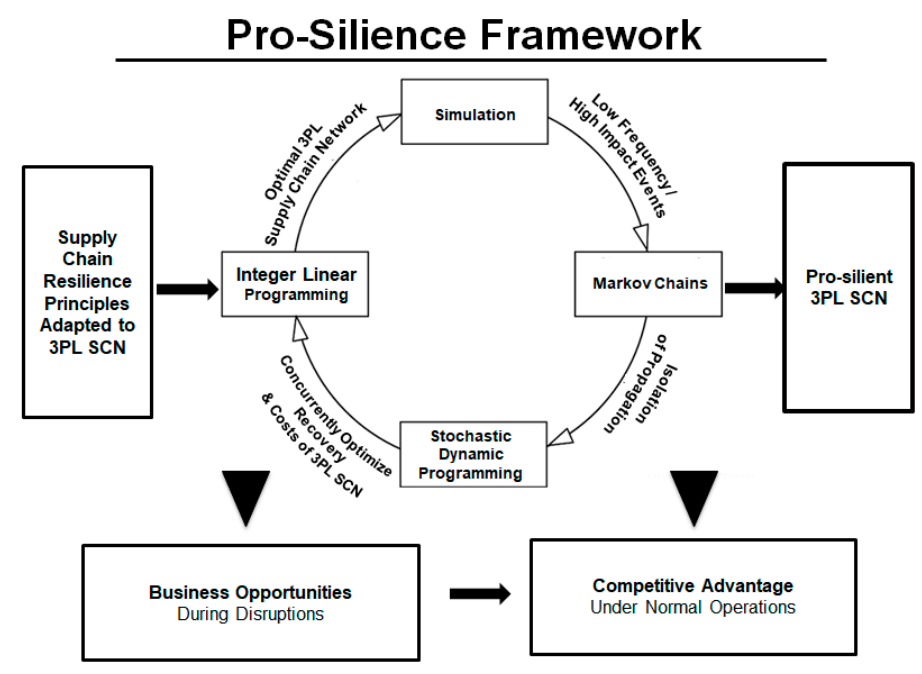

Figure 2. Conceptual model of pro-silience (own research).

We consider the principles of resilience as foundation (left hand side), namely (1) supply chain re-engineering, (2) collaboration, (3) agility, and (4) supply chain risk culture [20]. We adapt these elements to incorporate them within a 3PL SCN design, i.e., flexibility, velocity, information sharing, and redundancy. These principles are highly interdependent with each other [17]. Moreover, they may involve strategic decision on IT and collaborative systems. Hence, besides the traditional set of decisions regarding the physical layer in $\mathrm{SCN}$, design is extended with others.

The middle section of the framework addresses quantitative modelling of 3PL resilience as an ongoing dynamic process rather than a snapshot problem. In this process, companies trade off long-term resilience (cost) and business opportunities to short-term optimization of SCNs by a coherent set of OR/MS models [20]. Accordingly, by utilizing integer programming, stochastic programming, and simulation, both heuristics and optimization algorithms can maximize the pro-silience of a 3PL $\mathrm{SCN}$ in design (proactive), recovery (reactive), and regular operations. To illustrate, with the use integer linear programing, our aim is to develop an optimal 3PL SCN subject to a number of constraints i.e., markets, cost, and facilities. In addition, constraints such as weather conditions that can influence production volumes, cycle of the products, as well as peak season that can influence the demand, can be accommodated. Across a risk landscape that includes volcanoes, strikes, lean operations, pandemics, counterfeiting, and terrorism [54], 3PL SCNs must be structured contemplating real-world indicators and scenarios. By simulating the 3PL SCN, we can evaluate the optimal design under deviating conditions and unexpected events [130]. We can imitate the real world by architecting an artificial environment based on historical data of unexpected events and their impact as well as explicit business rules in cases where historical data do not apply [30]. As such, the 3PL SCN design can be evaluated whilst recovery strategies can be assessed including their associated costs. In our opinion, this is the most effective way to validate models and strategies.

Many articles have emphasized the global connectivity of supply chains [1,131-133]. In the event of unexpected shocks, disruptions will propagate through the network leading to even higher costs in terms of recovery. The most common way that disruptions are modelled in the literature is to assume that the supply chain process has two states, one in which it functions normally and one in which it is disrupted [30]. Subsequently, the framework is to isolate the propagation of the disturbances so as 
to not affect the different nodes in the network. To this end, the Markov chain property, where the transition probability from one state to another is independent on the past states of the process, can be utilized to model this. Thus, in each state of the supply chain process, a decision can be made to choose a recovery action to be taken and the transition probability from one state to other is dependent on the chosen recovery action. The deployment of such methodologies can help us to better understand how disruptions propagate and how these can be mitigated.

Finally, with the use of stochastic dynamic programming strategies to recover the network, including switching to different modes of transport, routing decisions as well as relocation of the transhipment hub (either individually or concurrently apply these) whilst minimizing the cost of the 3PL network can be explored. Simchi-Levi et al. [134] have developed a model for the robust formation of a SCN of medical supplies under uncertainty. Joint optimization of the inventory repositioning and distribution of medical supplies is considered to tackle all possible scenarios so that the SCN is prepared to operate cost effectively in the event of a bioterrorist attack. Such techniques can also be adopted in the design of a 3PL SCN whereas both inventory and distribution activities are integral part of the network, will provide scenario planning, and build pro-silience to enable the system to evaluate risk indicators. All appropriate recovery actions built in the system will allow the system to sense threats and, thus, recovery actions can be implemented before disruptions occur and continue normal operations when threats ceased. In essence, to configure a pro-silient 3PL SCN deliberately designed to anticipate disruptions and thrive when these occur and at the same be competitive enough under business as usual circumstances (right-hand side of model).

\section{Conclusions}

3PL SCN design is a combinatorial task seeking to optimally combine supplier, manufacturers, carriers, retailers, and customers subject to a number of constraints (under normal circumstances). At the same time, when major disruptions occur, many supply chains have the tendency to collapse and recover after only a long period of time. 3PL's ability to combine smooth regular operations with adaptability to difficult circumstances can furnish a true source of competitive advantage. SCI is crucial and hence pro-silient SCN design involves the physical, informational, and transactional layer in SCs. In business, outsourcing of logistics has gained increasing momentum over the last few years so that companies can focus on core business. However, transfer of responsibilities intrinsically means transfer of risks. Whereas daily operational risks can be dealt with by most 3PLs, black swan events are a different story.

The current literature has been amplified over the last few years, driven by high-profile disruptions. However, efforts of the research community have been mainly focused on defining SCR and identifying the principles that guide resilient behavior. Concerning limitations of the study, we have excluded qualitative papers due to the fact that previous literature reviews and researchers have recognized the lack of -and urgency for-the application of OR/MS methods. The objective of the paper was to produce new insights on 3PL supply chain networks resilience and the quantitative models developed by researchers to improve SCR whilst maintaining day-to-day performance under normal circumstances. Therefore, identification and accurate definition of 3PL network design and its incorporated risks comes first. On that basis, we add resilience principles to accommodate 3PLs operational domain, and by introducing a MS/OR based conceptual framework for pro-silience, we aim to guide future research.

Author Contributions: The literature review was performed and written by E.G.; H.K. contributed by guiding the research and giving feedback on the content of this paper, as well as revising parts of the manuscript All authors have read and agreed to the published version of the manuscript.

Funding: This research received no external funding.

Conflicts of Interest: The authors declare no conflict of interest. 


\section{References}

1. Blackhurst, J.; Craighead, C.W.; Elkins, D.; Handfield, R.B. An empirically derived agenda of critical research issues for managing supply-chain disruptions. Int. J. Prod. Res. 2005, 43, 4067-4081. [CrossRef]

2. Mari, S.I.; Lee, Y.H.; Memon, M.S. Sustainable and resilient supply chain network design under disruption risks. Sustainability 2014, 6, 6666-6686. [CrossRef]

3. Fiksel, J. Designing resilient, sustainable systems. Environ. Sci. Technol. 2003, 37, 5330-5339. [CrossRef] [PubMed]

4. Peck, H. Drivers of supply chain vulnerability: An integrated framework. Int. J. Phys. Distrib. Logist. Manag. 2005, 35, 210-232. [CrossRef]

5. Ji, G.; Zhu, C. Study on Supply Chain Disruption Risk Management Strategies and Model. In Proceedings of the IEEE International Conference on Service Systems and Service Management, Melbourne, Australia, 30 June-2 July 2008; pp. 1-6.

6. Hsiao, H.I.; Kemp, R.G.M.; Van der Vorst, J.G.A.J.; Omta, S.O. A classification of logistic outsourcing levels and their impact on service performance: Evidence from the food processing industry. Int. J. Prod. Econ. 2010, 124, 75-86. [CrossRef]

7. Murphy, P.R.; Daley, J.M. Profiling international freight forwarders: An update. Int. J. Phys. Distrib. Logist. Manag. 2001, 31, 152-168. [CrossRef]

8. Li, Y.; Xu, X.; Zhao, X.; Yeung, J.H.Y.; Ye, F. Supply chain coordination with controllable lead time and asymmetric information. Eur. J. Oper. Res. 2012, 217, 108-119. [CrossRef]

9. Third-Party Logistics Study "The State of Logistics Outsourcing". Results and Findings of the 23rd Annual Study. 2019. Available online: https://www.supplychain247.com/paper/2019_third_party_logistics_study_th e_state_of_logistics_outsourcing (accessed on 10 July 2019).

10. Hill, T. Operations Management, 2nd ed.; Palgrave Macmillan: Basingstoke, UK, 2005.

11. Slack, N.; Chambers, S.; Johnston, R. Operations Management; Pearson Education: London, UK, 2010.

12. Huo, B.; Selen, W.; Yeung, J.H.Y.; Zhao, X. Understanding drivers of performance in the 3PL industry in Hong Kong. Int. J. Oper. Prod. Manag. 2008, 28, 772-800. [CrossRef]

13. Yeung, J.H.Y.; Selen, W.; Sum, C.C.; Huo, B. Linking financial performance to strategic orientation and operational priorities. Int. J. Phys. Distrib. Logist. Manag. 2006, 36, 210-230. [CrossRef]

14. Costas Paris, Coronavirus Toll on Shipping Reaches \$350 Million a Week. The Wall Street Journal. 2020. Available online: https://www.wsj.com/articles/Coronavirus-toll-on-shipping-reaches-350-million-a-week-1 1581366671 (accessed on 10 February 2020).

15. Wackett, M. Coronavirus May Be Costing Container Shipping Lines \$350m Every Week. The Loadstar. 2020. Available online: https://theloadstar.com/Coronavirus-may-be-costing-container-shipping-lines-350m-eve ry-week/ (accessed on 10 February 2020).

16. Tang, C.S. Robust strategies for mitigating supply chain disruptions. Int. J. Logist. Res. Appl. 2006, 9, $33-45$. [CrossRef]

17. Kamalahmadi, M.; Parast, M.M. A review of the literature on the principles of enterprise and supply chain resilience: Major findings and directions for future research. Int. J. Prod. Econ. 2016, 171, 116-133. [CrossRef]

18. Pourhejazy, P.; Kwon, O.K. The new generation of operations research methods in supply chain optimization: A review. Sustainability 2016, 8, 1033. [CrossRef]

19. Rice, J.B.; Caniato, F.; Fleck, J.; Disraelly, D.; Lowtan, D.; Lensing, R.; Pickett, C. Supply Chain Response to Terrorism: Creating Resilient and Secure Supply Chains, Supply Chain; Response to Terrorism Project: Interim Report of Progress and Learnings; MIT Center for Transportation and Logistics: Cambridge, MA, USA, 2003.

20. Christopher, M.; Peck, H. Building the resilient Supply Chain. Int. J. Logist. Manag. 2004, 15, 1-13. [CrossRef]

21. Ponomarov, S.; Holcomb, M. Understanding the concept of supply chain resilience. Int. J. Logist. Manag. 2009, 20, 124-143. [CrossRef]

22. Ponis, S.T.; Koronis, E. Supply Chain Resilience? Definition of concept and its formative elements. J. Appl. Bus. Res. 2012, 28, 921-935. [CrossRef]

23. Kim, Y.; Chen, Y.S.; Linderman, K. Supply network disruption and resilience: A network structural perspective. J. Oper. Manag. 2015, 33, 43-59. [CrossRef]

24. Hoopes, L. Prosilience: Building Your Resilience for a Turbulent World; Dara Press: Brooklyn, NY, USA, 2017. 
25. Ivanov, D.; Dolgui, A. Viability of intertwined supply networks: Extending the supply chain resilience angles towards survivability. A position paper motivated by COVID-19 outbreak. Int. J. Prod. Res. 2020, 1-12. [CrossRef]

26. Kuehne + Nagel, Analyst Conference-First Quarter 2020 Results. Available online: https://www.kn-portal. com/about_us/investor_relations/financial_results_presentations/ (accessed on 27 April 2020).

27. Taleb, N.N.; Douady, R. Mathematical definition, mapping, and detection of (anti) fragility. Quant. Financ. 2013, 13, 1677-1689. [CrossRef]

28. Wang, J.; Muddada, R.R.; Wang, H.; Ding, J.; Lin, Y.; Liu, C.; Zhang, W. Toward a resilient holistic supply chain network system: Concept, review and future direction. IEEE Syst. J. 2014, 10, 410-421. [CrossRef]

29. Simchi-Levi, D.; Kaminsky, P.; Simchi-Levi, E. Designing and Managing the Supply Chain: Concepts, Strategies and Case Studies; McGraw-Hill: New York, NY, USA, 2000.

30. Snyder, L.V.; Atan, Z.; Peng, P.; Rong, Y.; Schmitt, A.J.; Sinsoysal, B. OR/MS models for supply chain disruptions: A review. IIE Trans. 2016, 48, 89-109. [CrossRef]

31. Ribeiro, J.P.; Barbosa-Povoa, A. Supply Chain Resilience: Definitions and quantitative modelling approaches-A literature review. Comput. Ind. Eng. 2018, 115, 109-122. [CrossRef]

32. Ivanov, D.; Dolgui, A.; Sokolov, B.; Ivanova, M. Literature review on disruption recovery in the supply chain. Int. J. Prod. Res. 2017, 55, 6158-6174. [CrossRef]

33. Eskandarpour, M.; Dejax, P.; Miemczyk, J.; Péton, O. Sustainable supply chain network design: An optimization-oriented review. Omega 2015, 54, 11-32. [CrossRef]

34. Longo, F.; Oren, T. Supply chain vulnerability and resilience: A state of the art overview. In Proceedings of the European Modeling \& Simulation Symposium, Amantea, Italy, 17-19 September 2008; pp. 17-19.

35. Braziotis, C.; Bourlakis, M.; Rogers, H.; Tannock, J. Supply chains and supply networks: Distinctions and overlaps. Supply Chain Manag. Int. J. 2013, 18, 644-652. [CrossRef]

36. Farahani, R.Z.; Rezapour, S.; Drezner, T.; Fallah, S. Competitive supply chain network design: An overview of classifications, models, solution techniques and applications. Omega 2014, 45, 92-118. [CrossRef]

37. Gorman, M.F.; Clarke, J.P.; Gharehgozli, A.H.; Hewitt, M.; de Koster, R.; Roy, D. State of the Practice: A Review of the Application of OR/MS in Freight Transportation. Interfaces 2014, 44, 535-554. [CrossRef]

38. Saenz, M.J.; Koufteros, X.; Hohenstein, N.O.; Feisel, E.; Hartmann, E.; Giunipero, L. Research on the phenomenon of supply chain resilience. Int. J. Phys. Distrib. Logist. Manag. 2015, 45, 90-117.

39. Fahimnia, B.; Tang, C.S.; Davarzani, H.; Sarkis, J. Quantitative models for managing supply chain risks: A review. Eur. J. Oper. Res. 2015, 247, 1-15. [CrossRef]

40. Gunasekaran, A.; Irani, Z.; Choy, K.L.; Filippi, L.; Papadopoulos, T. Performance measures and metrics in outsourcing decisions: A review for research and applications. Int. J. Prod. Econ. 2015, 161, 153-166. [CrossRef]

41. Khan, O.; Estay, D.A.S. Supply chain cyber-resilience: Creating an agenda for future research. Technol. Innov. Manag. Rev. 2015, 6-12. Available online: https://backend.orbit.dtu.dk/ws/portalfiles/portal/108130600/Supp ly_Chain_Cyber_Resilience.pdf (accessed on 18 May 2020). [CrossRef]

42. Tukamuhabwa, B.R.; Stevenson, M.; Busby, J.; Zorzini, M. Supply chain resilience: Definition, review and theoretical foundations for further study. Int. J. Prod. Res. 2015, 53, 5592-5623. [CrossRef]

43. Wankmüller, C.; Seebacher, G. A Citation Analysis of the Research on Supply Chain Resilience. In Proceedings of the 22nd EurOMA Conference, Neuchatel, Switzerland, 26 June-1 July 2015.

44. Elleuch, H.; Dafaoui, E.; Elmhamedi, A.; Chabchoub, H. Resilience and vulnerability in supply chain: Literature review. IFAC-Pap. 2016, 49, 1448-1453. [CrossRef]

45. Ivanov, D.; Dolgui, A.; Sokolov, B.; Ivanova, M. Disruptions in supply chains and recovery policies: State-of-the art review. IFAC-Pap. 2016, 49, 1436-1441. [CrossRef]

46. Oliveira, J.B.; Lima, R.S.; Montevechi, J.A.B. Perspectives and relationships in Supply Chain Simulation: A systematic literature review. Simul. Model. Pract. Theory 2016, 62, 166-191. [CrossRef]

47. Govindan, K.; Fattahi, M.; Keyvanshokooh, E. Supply chain network design under uncertainty: A comprehensive review and future research directions. Eur. J. Oper. Res. 2017, 263, 108-141. [CrossRef]

48. Bak, O. Supply chain risk management research agenda-From a literature review to a call for future research directions. Bus. Process Manag. J. 2018, 24, 567-588. [CrossRef]

49. Kochan, C.G.; Nowicki, D.R. Supply chain resilience: A systematic literature review and typological framework. Int. J. Phys. Distrib. Logist. Manag. 2018, 48, 842-856. [CrossRef] 
50. Macdonald, J.R.; Zobel, C.W.; Melnyk, S.A.; Griffis, S.E. Supply chain risk and resilience: Theory building through structured experiments and simulation. Int. J. Prod. Res. 2018, 56, 4337-4355. [CrossRef]

51. Roy, S.N.; Sengupta, T. Quintessence of third party (3PL) logistics. J. Glob. Oper. Strateg. Sourc. 2018, 11, 146-173. [CrossRef]

52. Wan, C.; Yang, Z.; Zhang, D.; Yan, X.; Fan, S. Resilience in transportation systems: A systematic review and future directions. Transp. Rev. 2018, 38, 479-498. [CrossRef]

53. Pickett, C. Prepare for supply chain disruptions before they hit. Logist. Today 2006, 47, 22-25.

54. Bhatia, G.; Lane, C.; Wain, A. Building Resilience in Supply Chains; World Economic Forum: Cologny, Switzerland, 2013.

55. Van Marle, G. Maersk ransomware attack has potential to disrupt 'tens of thousands' of shippers, warns analyst. The Loadstar. 2017. Available online: https://theloadstar.com/maersk-ransomware-attack-potential -disrupt-tens-thousands-shippers-warns-analyst/ (accessed on 28 June 2017).

56. Camparo, M.J. Wine and Seafood Piles up as China Virus Ripples Reach Chile; Bloomberg: New York, NY, USA, 2020; Available online: https://www.bloomberg.com/news/articles/2020-02-05/wine-and-seafood-pile-up-as -china-virus-ripples-reach-chile (accessed on 5 February 2020).

57. Iris, Ç.; Christensen, J.; Pacino, D.; Ropke, S. Flexible ship loading problem with transfer vehicle assignment and scheduling. Transp. Res. Part B Methodol. 2018, 111, 113-134. [CrossRef]

58. Deloitte, Supply Chain Resilience-a Risk Intelligent Approach to Managing Global Supply Chains. 2013. Available online: https:/www2.deloitte.com/global/en/pages/governance-risk-and-compliance/articles/risk-i ntelligent-approach-managing-supply-chains.html (accessed on 28 January 2019).

59. Kersten, W.; Hohrath, P.; Böger, M. An empirical approach to supply chain risk management: Development of a strategic framework. In Proceedings of the POMS2007 Conference, Dallas, TX, USA, 4-7 May 2007.

60. Hille, K.; McMorrow, R.; Liu, Q. Coronavirus Shakes Centre of World's Tech Supply Chain. Financial Times. 2020. Available online: https://www.ft.com/content/22345198-47e6-11ea-aeb3-955839e06441 (accessed on 5 February 2020).

61. Whelan, S. Forwarders Warned of Shortage of Cargo Space Once China Factories Reopen. The Loadstar. 2020. Available online: https:/theloadstar.com/forwarders-warned-of-shortage-of-cargo-space-once-china-factor ies-reopen/ (accessed on 4 February 2020).

62. Bret, D. Sea-Air Solutions Set to Help Alleviate Coronavirus Capacity Crunch. Aircargo News. 2020. Available online: https://www.aircargonews.net/airlines/sea-air-solutions-set-to-help-alleviate-Coronavirus-capaci ty-crunch/ (accessed on 12 February 2020).

63. Bartolacci, M.R.; Leblanc, L.J.; Kayikci, Y.; Grossman, T.A. Optimization modeling for logistics: Options and implementations. J. Bus. Logist. 2012, 33, 118-127. [CrossRef]

64. Heckmann, I.; Comes, T.; Nickel, S. A critical review on supply chain risk-Definition, measure and modeling. Omega 2015, 52, 119-132. [CrossRef]

65. Scheibe, K.P.; Blackhurst, J. Supply chain disruption propagation: A systemic risk and normal accident theory perspective. Int. J. Prod. Res. 2018, 56, 43-59. [CrossRef]

66. Ivanov, D.; Sokolov, B.; Dolgui, A. The Ripple effect in supply chains: Trade-off 'efficiency-flexibility-resilience'in disruption management. Int. J. Prod. Res. 2014, 52, 2154-2172. [CrossRef]

67. Ivanov, D. Simulation-based ripple effect modelling in the supply chain. Int. J. Prod. Res. 2017, 55, $2083-2101$. [CrossRef]

68. Tranfield, D.; Denyer, D.; Smart, P. Towards a Methodology for Developing Evidence-Informed Management Knowledge by Means of Systematic Review. Br. J. Manag. 2003, 14, 207-222. [CrossRef]

69. Popay, J.; Roberts, H.; Sowden, A.; Petticrew, M.; Arai, L.; Rodgers, M.; Britten, N.; Roen, K.; Duffy, S. Guidance on the Conduct of Narrative Synthesis in Systematic Reviews: A Product of the ESRC Methods Programme; University of Lancaster: Lancaster, UK, 2006.

70. Barbosa-Póvoa, A.P. Optimising sustainable supply chains: A summarised view of current and future perspectives. In Optimization and Decision Support Systems for Supply Chains; Springer: Berlin/Heidelberg, Germany, 2017; pp. 1-11.

71. Higgins, J.P.T.; Thomas, J.; Chandler, J.; Cumpston, M.; Li, T.; Page, M.J.; Welch, V.A. (Eds.) Cochrane Handbook for Systematic Reviews of Interventions Version 6.0 (Updated July 2019). Cochrane. 2019. Available online: www.training.cochrane.org/handbook (accessed on 10 January 2018).

72. Mefford, R.N. The financial crisis and global supply chains. AIB Insights 2000, 9, 8-11. 
73. PRISMA Transparent Reporting of Systematic Reviews and Meta-Analyes. Available online: http://www.pr isma-statement.org (accessed on 5 January 2018).

74. Frohlich, M.T.; Westbrook, R. Arcs of integration: An international study of supply chain strategies. J. Oper. Manag. 2001, 19, 185-200. [CrossRef]

75. Van der Vaart, T.; Van Donk, D.P. A critical review of survey-based research in supply chain integration. Int. J. Prod. Econ. 2008, 111, 42-55. [CrossRef]

76. Jüttner, U.; Maklan, S. Supply chain resilience in the global financial crisis: An empirical study. Supply Chain Manag. Int. J. 2011, 16, 246-259. [CrossRef]

77. Liu, C.L.; Lee, M.Y. Integration, supply chain resilience, and service performance in third-party logistics providers. Int. J. Logist. Manag. 2018, 29, 5-21. [CrossRef]

78. Giri, B.C.; Sarker, B.R. Improving performance by coordinating a supply chain with third party logistics outsourcing under production disruption. Comput. Ind. Eng. 2017, 103, 168-177. [CrossRef]

79. Noroozi, A.; Mazdeh, M.M.; Heydari, M.; Rasti-Barzoki, M. Coordinating order acceptance and integrated production-distribution scheduling with batch delivery considering Third Party Logistics distribution. J. Manuf. Syst. 2018, 46, 29-45. [CrossRef]

80. Ma, X.; Wang, S.; Islam, S.M.; Liu, X. Coordinating a three-echelon fresh agricultural products supply chain considering freshness-keeping effort with asymmetric information. Appl. Math. Model. 2019, 67, 337-356. [CrossRef]

81. Cai, X.; Chen, J.; Xiao, Y.; Xu, X.; Yu, G. Fresh-product supply chain management with logistics outsourcing. Omega 2013, 41, 752-765. [CrossRef]

82. Chan, C.K.; Zhou, Y.; Wong, K.H. A dynamic equilibrium model of the oligopolistic closed-loop supply chain network under uncertain and time-dependent demands. Transp. Res. Part E Logist. Transp. Rev. 2018, 118, 325-354. [CrossRef]

83. Tsang, Y.P.; Choy, K.L.; Wu, C.H.; Ho, G.T.S.; Lam, H.Y.; Tang, V. An intelligent model for assuring food quality in managing a multi-temperature food distribution centre. Food Control 2018, 90, 81-97. [CrossRef]

84. Vilko, J.P.; Hallikas, J.M. Risk assessment in multimodal supply chains. Int. J. Prod. Econ. 2012, 140, 586-595. [CrossRef]

85. Tezuka, K. Rationale for utilizing 3PL in supply chain management: A shippers' economic perspective. IATSS Res. 2011, 35, 24-29. [CrossRef]

86. Wilding, R.; Wagner, B.; Colicchia, C.; Strozzi, F. Supply chain risk management: A new methodology for a systematic literature review. Supply Chain Manag. Int. J. 2012, 17, 403-418.

87. Govindan, K.; Chaudhuri, A. Interrelationships of risks faced by third party logistics service providers: A DEMATEL based approach. Transp. Res. Part E Logist. Transp. Rev. 2016, 90, 177-195. [CrossRef]

88. Pfohl, H.; Gallus, P.; Thomas, D. Interpretive structural modeling of supply chain risks. Int. J. Phys. Distrib. Logist. Manag. 2011, 41, 839-859. [CrossRef]

89. Zhang, H.; Okoroafo, S.C. Third-party logistics (3PL) and supply chain performance in the Chinese market: A conceptual framework. Eng. Manag. Res. 2015, 4, 38. [CrossRef]

90. Nel, J.; De Goede, E.; Niemann, W. Supply chain disruptions: Insights from South African third-party logistics service providers and clients. J. Transp. Supply Chain Manag. 2018, 12, 1-12. [CrossRef]

91. Sheffi, Y. Resilience reduces risk. Off. Mag. Logist. Inst. 2006, 12, 13-14.

92. Chopra, S.; Sodhi, M.S. Supply-chain breakdown. MIT Sloan Manag. Rev. 2004, 46, 53-61.

93. Third-Party Logistics Study "The State of Logistics Outsourcing". Results and Findings of the 17th Annual Study. 2013. Available online: https://www.capgemini.com/wp-content/uploads/2017/07/2013_Third-Party_ Logistics_Study.pdf (accessed on 6 June 2019).

94. MacKenzie, C.A.; Santos, J.R.; Barker, K. Measuring changes in international production from a disruption: Case study of the Japanese earthquake and tsunami. Int. J. Prod. Econ. 2012, 138, 293-302. [CrossRef]

95. Lennane, A. DSV Links with Panalpina for 'a Unique Solution' Flying in and Out of China. The Loadstar. 2020. Available online: https://theloadstar.com/dsv-links-with-panalpina-for-a-unique-solution-flying-in-a nd-out-of-china/ (accessed on 24 February 2020).

96. DSV Opens Cargo Air Bridge between China and the US. DSV Press Release. 2020. Available online: https:/www.dsv.com/About-DSV/media/latest-news/2020/02/DSV-opens-cargo-air-br idge-between-China-and-the-US (accessed on 24 February 2020). 
97. Brouer, B.D.; Dirksen, J.; Pisinger, D.; Plum, C.E.; Vaaben, B. The Vessel Schedule Recovery Problem (VSRP)_A MIP model for handling disruptions in liner shipping. Eur. J. Oper. Res. 2013, 224, 362-374. [CrossRef]

98. Iris, Ç.; Lam, J.S.L. Recoverable robustness in weekly berth and quay crane planning. Transp. Res. Part B Methodol. 2019, 122, 365-389. [CrossRef]

99. Lam, J.S.L.; Bai, X. A quality function deployment approach to improve maritime supply chain resilience. Transp. Res. Part E Logist. Transp. Rev. 2016, 92, 16-27. [CrossRef]

100. Chatfield, D.C.; Harrison, T.P.; Hayya, J.C. SISCO: An object-oriented supply chain simulation system. Decis. Support Syst. 2006, 42, 422-434. [CrossRef]

101. Rajagopal, V.; Venkatesan, S.P.; Goh, M. Decision-making models for supply chain risk mitigation: A review. Comput. Ind. Eng. 2017, 113, 646-682. [CrossRef]

102. Wu, Y. A dual-response strategy for global logistics under uncertainty: A case study of a third-party logistics company. Int. Trans. Oper. Res. 2012, 19, 397-419. [CrossRef]

103. Ko, H.J.; Evans, G.W. A genetic algorithm-based heuristic for the dynamic integrated forward/reverse logistics network for 3PLs. Comput. Oper. Res. 2007, 34, 346-366. [CrossRef]

104. Kayvanfar, V.; Sajadieh, M.S.; Husseini, S.M.M.; Karimi, B. Analysis of a multi-echelon supply chain problem using revised multi-choice goal programming approach. Kybernetes 2018, 47, 118-141. [CrossRef]

105. Hu, L.; Zhu, J.X.; Wang, Y.; Lee, L.H. Joint design of fleet size, hub locations, and hub capacities for third-party logistics networks with road congestion constraints. Transp. Res. Part E-Logist. Transp. Rev. 2018, 118, 568-588. [CrossRef]

106. Janić, M. Modeling the resilience of an airline cargo transport network affected by a large scale disruptive event. Transp. Res. Part D Transp. Environ. 2019, 77, 425-448. [CrossRef]

107. Janić, M. Reprint of "Modelling the resilience, friability and costs of an air transport network affected by a large-scale disruptive event". Transp. Res. Part A Policy Pract. 2015, 81, 77-92. [CrossRef]

108. Ishfaq, R. Resilience through flexibility in transportation operations. Int. J. Logist. Res. Appl. 2012, 15, 215-229. [CrossRef]

109. Hendriks, M.P.M.; Armbruster, D.; Laumanns, M.; Lefeber, E.; Udding, J.T. Design of robust distribution networks run by third party logistics service providers. Adv. Complex Syst. 2012, 15, 1150024. [CrossRef]

110. Rahbari, A.; Nasiri, M.M.; Werner, F.; Musavi, M.; Jolai, F. The vehicle routing and scheduling problem with cross-docking for perishable products under uncertainty: Two robust bi-objective models. Appl. Math. Model. 2019, 70, 605-625. [CrossRef]

111. Leung, L.C.; Wong, W.H.; Hui, Y.V.; Wan, Y. Managing third-party logistics under uncertainty: A decision scheme and managerial implications. Int. J. Prod. Econ. 2013, 145, 630-644. [CrossRef]

112. Cheong, M.L.; Bhatnagar, R.; Graves, S.C. Logistics network design with supplier consolidation hubs and multiple shipment options. J. Ind. Manag. Optim. 2007, 3, 51.

113. Colicchia, C.; Dallari, F.; Melacini, M. Increasing supply chain resilience in a global sourcing context. Prod. Plan. Control 2010, 21, 680-694. [CrossRef]

114. Yang, Y.; Pan, S.; Ballot, E. Freight transportation resilience enabled by physical internet. IFAC-Pap. Online 2017, 50, 2278-2283. [CrossRef]

115. Naim, M.; Aryee, G.; Potter, A. Determining a logistics provider's flexibility capability. Int. J. Prod. Econ. 2010, 127, 39-45. [CrossRef]

116. Huo, B.; Ye, Y.; Zhao, X. The impacts of trust and contracts on opportunism in the 3PL industry: The moderating role of demand uncertainty. Int. J. Prod. Econ. 2015, 170, 160-170. [CrossRef]

117. Fartaj, S.R.; Kabir, G.; Eghujovbo, V.; Ali, S.M.; Paul, S.K. Modelling transportation disruptions in the supply chain of automotive parts manufacturing company. Int. J. Prod. Econ. 2019, 222, 107511. [CrossRef]

118. Kristianto, Y.; Gunasekaran, A.; Helo, P.; Hao, Y. A model of resilient supply chain network design: A two-stage programming with fuzzy shortest path. Expert Syst. Appl. 2014, 41, 39-49. [CrossRef]

119. Ghadge, A.; Dani, S.; Kalawsky, R. Supply chain risk management: Present and future scope. Int. J. Logist. Manag. 2012, 23, 313-339. [CrossRef]

120. Iris, C.; Asan, S.S. A review of genetic algorithm applications in supply chain network design. In Computational Intelligence Systems in Industrial Engineering; Atlantis Press: Paris, France, 2012; pp. 203-230.

121. Cruijssen, F.C.A.M. Horizontal Cooperation in Transport and Logistics; Tilburg University: Tilburg, The Netherlands, 2006. 
122. Boyes, H. Cybersecurity and cyber-resilient supply chains. Technol. Innov. Manag. Rev. 2015, 5, 28. [CrossRef]

123. Ivanov, D. Predicting the impacts of epidemic outbreaks on global supply chains: A simulation-based analysis on the coronavirus outbreak (COVID-19/SARS-CoV-2) case. Transp. Res. Part E Logist. Transp. Rev. 2020, 136, 101922. [CrossRef]

124. Associated Press. Tulips from Amsterdam? Not During Coronavirus Crisis. 2020. Available online: https://www. voanews.com/science-health/coronavirus-outbreak/tulips-amsterdam-not-during-coronavirus-crisis (accessed on 18 May 2020).

125. Breuer, C.; Siestrup, G.; Haasis, H.D.; Wildebrand, H. Collaborative risk management in sensitive logistics nodes. Team Perform. Manag. 2013, 19, 331-351. [CrossRef]

126. Manuj, I.; Mentzer, J.T. Global supply chain risk management strategies. Int. J. Phys. Distrib. Logist. Manag. 2008, 38, 192-223. [CrossRef]

127. Parkin, B.; Wilkes, W. Trucks Are Filling a 6,000 Mile Beijing-to-Berlin Supply Gap. Bloomberg. 2020. Available online: https://www.bloomberg.com/news/articles/2020-04-30/truckers-are-filling-a-6-000-mile-be ijing-to-berlin-supply-gap (accessed on 18 May 2020).

128. Bhattacharya, A.; Geraghty, J.; Young, P.; Byrne, P.J. Design of a resilient shock absorber for disrupted supply chain networks: A shock-dampening fortification framework for mitigating excursion events. Prod. Plan. Control 2013, 24, 721-742. [CrossRef]

129. Deng, X.; Yang, X.; Zhang, Y.; Li, Y.; Lu, Z. Risk propagation mechanisms and risk management strategies for a sustainable perishable products supply chain. Comput. Ind. Eng. 2019, 135, 1175-1187. [CrossRef]

130. Saanen, Y.A.; Valkengoed, M.V. Comparison of three automated stacking alternatives by means of simulation. In Proceedings of the Winter Simulation Conference, Orlando, FL, USA, 4-7 December 2005.

131. Wagner, S.M.; Bode, C. An empirical investigation into supply chain vulnerability. J. Purch. Supply Manag. 2006, 12, 301-312. [CrossRef]

132. Stecke, K.E.; Kumar, S. Sources of supply chain disruptions, factors that breed vulnerability, and mitigating strategies. J. Mark. Channels 2009, 16, 193-226. [CrossRef]

133. Christopher, M.; Holweg, M. "Supply Chain 2.0": Managing supply chains in the era of turbulence. Int. J. Phys. Distrib. Logist. Manag. 2011, 41, 63-82. [CrossRef]

134. Simchi-Levi, D.; Trichakis, N.; Zhang, P.Y. Designing response supply chain against bioattacks. Oper. Res. 2019, 67, 1246-1268. [CrossRef] 